$\begin{array}{cccc}\text { 吸収 の 発展象 } & \\ & & \text { 八田四郎次** }\end{array}$

\section{9 世紀における発展}

液体によるガスの吸収は実験室でる化学工場でる広く 使われる操作である。実験室ではるっぱら気泡式ハッチ 型が用いられる。Solvay 法による炭酸ソーダの製造は 1866 年頃には工業化されているが，1872 年に Solvay 塔が発明されるまでは，食塩水への $\mathrm{NH}_{3}$ および $\mathrm{CO}_{2}$ の 吸収は気泡式バ,型であったようである。しかし工業 的には旧くから全続操作が普通であり，その装置は大別 して充填塔式と段塔式とである。

充填䓵の最初は 1836 年イギリス人 Wm. Gossage の 水による HCl ガス吸収用のコークス荅である。Le Blanc 法において食塩と浱硫酸との加熱によって副生する $\mathrm{HCl}$ を吸収して空気の污染を防止したのである。これよ り前, 1827 年に鉊室式硫酸工業における排ガス中の酸化 窒素の吸収回収のために Gay Lussac 塔が発明された が，実際の建設は 1842 年であり，本格的な活用は酸化 窒素放散用の Glover 塔が 1862 年に発明されて以後で ある。それから間むなく 1872 年に Solvey 塔ができた。 これは曼収に伴なって生成する $\mathrm{NaHCO}_{3}$ の結晶を円滑 に降下させるために構造はやや巽なっているが気泡式段 荅である。

以上の充填塔も段塔も，なるへく広い接触面榬をすっ て液とガスとを向流接触させるよう工夫されたすのであ り,両者の中で何れが優るかに関する Hurter と Lunge との 1885 年以来数年間にわたる論竓は興味深いるので ある。

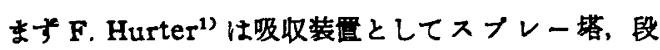
塔, 充填塔の 3 者を採り，種々の技術的問題を简単な数 式計算に基ついて比較検討し，結局充填塔が段塔に優 ク、スフレー塔がすっとる劣ると断している。これに対 して G. Lunge ${ }^{2)}$ は自らが工夫した Lunge 塔 (LungeRohrman 塔ともいう）が充填塔飞传ると主張してい る。これは耐酸陶器製の多孔板式段塔であり，各段こと に液を均一に分布するよ5工夫されている。

Hurter は数学に長した技術者であり，その論文によ

- 昭和 38 年 10 月 10 日曼理

** 千代田化工思杸（株）
ると漠然ながら充填塔の作業容量のような概念を持って いたよラに思われる。しかし理論す実験データす不十分 な状態においての Hurter の結論には疑問が残されてい る。じっさい段塔である Lunge 塔がそののちドイッで は所々に建設されて充填塔に優るとのデータる出てい る。その Lunge 塔がもっと発展しなかった理由は解ら ないが，筆者は当時原料ガスの精製が不十分で，段上に 固体不純物が蓄栍したのではなからうかと考える。

そののち充填塔が広く使われるようになり、コークス や軽石の法かに諸種の人工充填物が考案された。1901年 出版の Davis ${ }^{3)}$ の Hand book にも Guttman Ball など の充填物が記されている。

\section{0 世紀における発展の大要}

今世紀当初の約 20 年間は曼叹に関しては格別の 発 展 は見られない。工業的吸収には広く充填塔が使われ，そ れにつれて種々の形の充填物が提出されているが，じっ さいにどれだけ採用されたか，またその長短優劣などは 解からない。生き残って現在使われているすのは Raschig Ring, Berl Saddle, Interlox Saddle 位だけであ る。 Raschig Ringは1914年ドイッのE. Raschig の発 明であるが，この年は第 1 次大戦の初年であるから世界 に広まったのは戦後である。Berl Saddle は1931年ド イッの E. Berl の発明であり, Interlox Saddle は 1950 年頃フメリカの Max Levaによって発明されたもので ある。

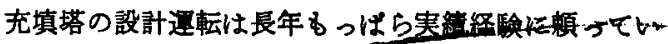
たが，1919年頃からこれに阅する研究が始まった。それ

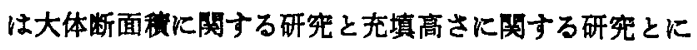
分けられる。前者はすでに一応解決されている。しかし 充填高さに関しては幾多の報文があるが今な的確実な成 果は得られておらず，とくに反応を伴なら吸収荅の高さ の設計は理論だけでは解決できないのである。

吸収の学術的研究としては，接触面棲を一定にして， 単位面稜からの吸収速度を検討せねばならない。数多く の研宪によって反応を伴なわない揚合は大体解明された が，反応吸収については脣年の多数の研究に拘らず今な お前途が遗いよ5である。 
以下に発展の概要を述へる。文献は多過きるので衆知 のものや本誌の総索引（1962）によって容易に解るもの はなるへく省略するを原則とした。

\section{単位面積からのカス吸収の研究}

ガス吸収に関心を有する技術者は旧くから暗黙の中に 吸収速度について

$$
W=A N=A K_{G}\left(P_{G}-P^{*}\right)=A K_{L}\left(C^{*}-C_{L}\right)
$$

の概念を持っていたと思5。すなわち吸収の推進力は $P_{G}-P^{*}$ または $C^{*}-C_{L}$ であり, 吸収速度 $W$ は接触面 㮐 $A$ に比例することを認識していた。それで装圈は接 触面糟を大にするようエ夫し，かつなるへく十分に吸収 して符厚夜を得るために推進力を考䍐して夜ガス向流式 を採用したのであろう。しかし比例俰数 $K_{G}$ または $K_{L}$ の内容については全く解っていなかったのである。

この問題の取初の研究が 1924 年の Whitman の二重 境膜説である。すなわち接触面の両側にガス境膜と液境 膜が存在してその拡散抵抗が吸収速度を支眍し，接触面 における溶解作用には抵抗なしと仮定して次の結果を得 た。

$$
\begin{gathered}
W / A=N=\frac{D_{G}}{X_{G}}\left(P_{G}-P_{i}\right)=\frac{D_{L}}{X_{L}}\left(C_{i}-C_{L}\right) \\
C_{i}=H P_{i}
\end{gathered}
$$

この両式に制拠し, かつ

$$
\begin{aligned}
& P^{*}=C_{L} / H ; \quad C^{*}=H P_{G} \\
& k_{G}=D_{G} / k_{G} ; \quad k_{L}=D_{L} / X_{L} \\
& \frac{1}{K_{G}}=\frac{1}{k_{G}}+\frac{1}{H k_{L}}=\frac{1}{H K_{L}}
\end{aligned}
$$

とおけば

$$
\begin{aligned}
& N=k_{G}\left(P_{G}-P_{i}\right)=k_{L}\left(C_{i}-C_{L}\right) \\
& N=K_{G}\left(P_{G}-P^{*}\right)=K_{L}\left(C^{*}-C_{L}\right)
\end{aligned}
$$

が得られる。（8）は上述の（1）と同じであり，二重境

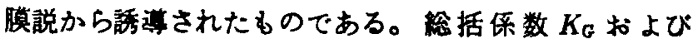
$K_{L}$ の物理的意義が（6）で表わされ，各境膜ことの係数 $k_{G}, k_{L}$ は払散係数 $D$ を境膜の厚さ $X$ で除したるので表 わされたのである。本説の考え方および結果はこの分野 における贯重な文献であり，そののらの物質移動の研究 や充填塔に関する研究を促進し，ひとりガス吸収のみな らを異相間の物筫移動操作の研究に大なる貫献をしたの である。

さて二重境膜説は定常拆散に涪执しているが，充填塔 などでは液が薄居流をなし，新らしい面がつきつきにで きるから定常払散の仮定には疑問がある。1931 年 New. $\operatorname{man}^{5)}$ は一定原さの液首内への不定常拡散に算拠した 吸収速度式を得た。これはフーリエ級数で表わされる。

筆者()す 1934 年同じ問題を㭘討し, 幅 $a$, 深さ $b$, 平

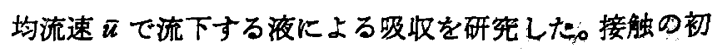
期には被吸収ガスが夜風の底部に達しないから深さが無 限大の場合と变らないことに注目して

$$
W=a b \bar{u}\left(\bar{C}-C_{L}\right)=\frac{2}{\sqrt{\pi}} \sqrt{\bar{u} D_{L} x}\left(C_{i}-C_{L}\right)
$$

なる結果を得た。 $\bar{C}$ は流下距離 $x$ における平均溇度で ある。筆者は本式を Newman の式と比較して $\left(\bar{C}-C_{L}\right) /\left(C_{i}-C_{L}\right)<0.520$ の範囲に適用できることを 明らかにした。

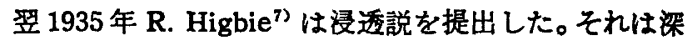
さ無限大の夜層への被吸収ガスの表面からの拡散速度を 求めたものであり， $t=0 \sim t$ 間の平均吸収速度は

$$
N=\frac{2}{\sqrt{\pi}} \sqrt{\frac{D_{L}}{t}}\left(C_{i}-C_{L}\right)
$$

となる。本式は実質的には筆者の（9）と変らないのて ある。しかし Higbie は別の表現法を採った。すなわち (7) にならって

$$
N=k_{L}\left(C_{i}-C_{L}\right)
$$

で表わし，(10), (11) から

$$
k_{L}=\frac{2}{\sqrt{\pi}} \sqrt{\frac{\overline{D_{L}}}{t}}
$$

を得た。これが浸透説による $k_{L}$ である。

今まで二重境膜説たけの間は（5）（7）両式の中で何 れが $k_{L}$ の定義式かはっきりせず，むしろ前者のよ5に 考えられていた。筆者もその1人であった。しかるに Higbie によって，（7）すなわち（11）が $k_{L}$ の定義を表 わすこと, 二重境膜説では（5）となり，浸透説では（12） となることが明らかになったのである。この点が Higbie の大なる頁献である。

それまで $k_{L}$ は「境膜係数」(物質移動の) と呼ばれ ていたがそれれ暗然の中に（5）式を示唆していたよ 5に思5。Higbie およびそれ以後の研究によるとこの 語は些か不培当であり，「物質移動係数」の語が使われ るようになって来たのである。

つぎイギリスの Danckwerts ${ }^{8)}$ は表面更新説を提 出した。工業装置では接触面がたえず更新する。いま既 存の表面メレメントの消失率をその年㱓に無関係と仮定 すると，年龄分布は $s e^{-a t}$ となり，各エレメントからの 吸収速度を Higbie の瞬間速度に従がうすると吸収速 度は

$$
N=\sqrt{D s}\left(C_{i}-C_{L}\right)
$$

となり， $k_{L}$ の定義（7）を用いると次の式が得られる。

$$
k_{L}=\sqrt{D_{L} S}
$$

さらに 1958 年には Toor の film-penetration concept が発表された。それは境膜説と表面更新説とを組合 
わせたもので、注目の価値あるるのと思われる。

\section{反応を伴なう吸収}

筆者103 1928 年はじめて瞬間反応を伴な了吸収につ いて研究し，ついで 1932 年に非瞬間反応の場合を解い た。それは定常拡散の二重境膜説に準拠したのである。 非瞬間反応の場合は

$$
N=\beta k_{L}\left(C_{i}-C_{L}\right)
$$

で表わされ， $\beta$ は $\gamma=\left(\sqrt{\left(k C_{B} D_{L}\right)} / k_{L}\right)$ の関数である。 $C_{B}$ は反応物の浱度, $k$ は二次反応の速度定数である。

1947 8 年 Van Krevelen and Hoftijzer ${ }^{111}$ 梳者の 考え方に準拠して広く深く追究している。瞬間反応の場 合も非瞬間反応の極限として図解された。

以上は定常拡散に草拠したのであるが, 1952 年 T. K. Sherwood and R. L. Pigford ${ }^{12)}$ は浸透説に準拠して瞬 間反応を伴なう吸収を解いた。その結果は複雑である が，液中の被吸収ガスと反応物との拡散俰数が等しいと きには筆者の二重境膜に洋拠した䇠単な解と合致するの は興味あることである。

また 1950 年 Danckwerts ${ }^{13)}$ 悱瞬間反応の場合を浸 透説に準拠して解き

$$
\beta=\left(\gamma+\frac{\pi}{8} \cdot \frac{1}{\gamma}\right) \operatorname{erf}\left(\frac{2 \gamma}{\sqrt{\pi}}\right)+\frac{1}{2} e^{-\left(4 \tau^{2} / \pi\right)}
$$

を得た。上述の筆者の場合の $\beta=\gamma / \tan \mathrm{h} \gamma$ と数值的に はとんど変らないのは興味梁い。ちなみに松山卓藏氏が 同じ年に同じテーマを解いて本誌に発表されたが，最後 の高級な分計算に誤があるのは惜しいことである。

さらに本年 Huang ${ }^{10)}$ は Toor の film-penetration concept に準扰して反応吸収の一般解を提出している。

反応受収の理論の最後に接触面の洤度 $C_{\boldsymbol{i}}$ について付 言したい。化学反庆を起こす溶液に対しては真の物理的 溶解度とい5ものはあり得ないわけであり， $C_{i}$ は擬溶 解度 (Pseudo-solubility) である。それは純溶媒の場 合よりる小さいことは推定されるが真の值はわからな い。擬溶解度に関しては文献は見当らない。筆者はこれ が反応吸収に拊る一つの盲点と思う。

さて, 以上の理論的研究とならんで多くの実験的研究 が行なわれた。この研究のためには接触面䅡を明確に知 る必要がある。筆者 ${ }^{6)}$ は幅一定の傾斜面を用いたが，そ ののち多くの研究者は需壁塔を用いている。濡壁塔は 1934 年 Gilliland and Sherwood ${ }^{16)}$ が液ガス間の物質 移動におけるガス側の抵抗の研究に用いたのであるが, 液側の抵抗の研究にる好適なので広く利用されて来た。 この方面にはわが国にる藤田重文 $5^{16)}$, 疋田晴夫ら ${ }^{17)}$,
亀井三郎ら ${ }^{18)}$ の諸研究がある。藤田らはよく文献を精査 乙, 自らの実験と比較検討して貴重な結果を得ており, 定田らは実測值が一般に理論值より大なることの理由を 検討し，波立ちの影響や物性の影響む研究している。近 くは只木植力らの研究もある。とにかく平滑な表面上を 流れる液体の状態が決して簡単なるのでないことがこれ らの実験によっても明らかに示されている。また波立ち が表面張力に関係のあることは明らかであろうが，その 現象の本質については格別の研究はない上5に思5。

\section{尧填塔に関する研究}

充填塔の設計では充填層の断面積と高さとの二つが主 問題である。

塔の断面䅡に関しては 1919 年の Zeisberg の研究が 最初であるが, 1931 年には Chilton and Colburn の頭 損失の研究があり，その後多くの研究によって頭損失や 溢汪条件などが一応解明されて合理的な設計ができるよ らになった。しかしその内容は本来流動現象であり，吸 収との関係が間接的であるから本稿では省略したい。た たし内田俊一，藤田重文 ${ }^{20}$ 両氏の 1934 年以来の研究が 本問題の解明に頁献大なることは省略できない。

充填荅の研究においては液ガスの分布と接触面積の問 題がある。これは断面積と高さとの両方に関係があるが もっぱら実験によらねばならない。液の分布に関しては 旧く 1893 年の Hurter ${ }^{1)}$ の研究ののちに, Kirschbaum (1931 年) ${ }^{21)}$, Baker 5 ${ }^{22)}$, 内田, 藤田 ${ }^{23)}$ の研究 がある。また，需れ面積については 1935 年 $\mathrm{Mayo}^{24)} ら$ の直接測定があり，1956 年疋田晴夫ら ${ }^{25)}$ の測定すある。 そののち多くの間接的の研究がありこれによると濡れ 面稓が全部有効面積 (active area) でないことも明ら かになった。しかしてこれらの研膋を総合すると，液は 層内を流下する間に分布の不均一さが增すこと, 溢流に 近ついても充填物の全表面が需れるに至らないことなど の推論は一致しているが，扣互いの結果には大分大きい 異同が見られるのである。

さて充填高さの設計のための研究は 1927 年 Lewis and McAdams がはじめてであり, 二重境膜説に準拠し て榙の容量係数の概念が得られたことは采知のことくで ある。ついで Chilton and Colburn ${ }^{27)}$ が H. T. U.の 概念を導入した。その基礎は Lewis らと変らないが, 性能を表わすのに単なる長さを用いるのが長所である。

この両研究に刺激されてそののち容量保数や H. T. U に関してきわめて多数の研究がなされて来た。また容量

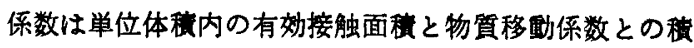
であるから，これを分離してそれぞれの特性を明らかに 
しようとする研究す数多くなされている。わが国では藤 田重文ら, 疋田晴夫ら, 恩田格三郎と佐田栄三28)ら少な くないが文献は総索引（1962）にゆずる。

\section{㭪足}

以上を省みると，80年ほど前に Hurter が段塔に比 へて充填塔が優ると指摘して以来, 吸収には主として充 填塔が用いられ，いろいろの人工充填物が提案された が，今日使われているのは2 3 種のみで，これらに対し てはその特性を明らかにするためにきわめて多数の研究 が発表された。しかしこれらの発表を見ると、データに ばらつきが大きく，また液およびガスの分布が不均一で

\section{女}

1) F. Hurter: J. Soc. Chem. Ind., 4, 639 \& 1885 (1885) ; 8, 707 (1887) ; 8, 861 (1889); 12, 227 \& 989 (1893)

2) G. Lunge: J. Soc. Chem. Ind., 12, 417 (1893); $Z$. angew. Chem., 12, 328 (1893)

3) G. E. Davis: "A Handbook of Chemical Engineering," 1st Ed. (1901); 2nd Ed. (1906).

4) W. K. Lewis and W. G. Whitman: Ind. Eng. Chem., 16. 1215 (1924)

5) A. B. Newman : Trans. Am. Inst. Chem. Engrs., 27, 310 (1931)

6) 八田四郎次, 工化, 37, $601 \& 611$ (1931)

7) R. Higbie : Trans. Am. Inst. Chem. Engrs., 31, 365(1935)

8) P. V. Danckwerts : Ind. Eng. Chem., 43, 1460 (1951)

9) H. L. Toor and J. M. Marchells : A. I. Ch. E. Journal, 4, 97 (1958)

10）八田四郎不, 工化, 31, 869 (1928)：32, 809 (1929)； 35, 1389 \& 1397 (1932)

11) D. W. Van Krevelen and P. J. Hoftijzer : Rec. des Trav. Chim. des Pays-Bas, 88, 49, 61, 513 (1947); 67, 133, 563, 587 (1948) ; Chem. Eng. Progress, 44, 529(1948)

12) T. K. Sherwood and R. L. Pigford: "Absorption and Extraction," 2nd Ed. (1952), pp. 332-7

13) P. V. Danckwerts: Trans. Faraday Soc., 46, 300 (1950)

14) C. J. Huang and C. H. Kus: A. I. Ch. E. Journal, 9, 161
再現性が满足とは思われず，かつ太さ，高さの大型化と ともに低下することがわかって来たので旧いHurter の 説は無条件に肯定できない。実際今日では大型のるのは 専ら段塔が用いられて㧍り，中型でも段塔が望ましい場 合が多いかと考える。段塔は歴史的には蒸留から発展し たが，今日では吸収用としてもきわめて重要なるのであ る。その段奻率は物筫移動の理論から研究されている。 吸収装䁂としては以上と全く遧ったものの開発す望ま しい。ウェンチュリースクラッバーはガス中の固体また は液体の䃍粒子の除去を目的とするすのであるが，特定 の吸收操作にす使われる。また矢木栄ら 29 の垂直管およ び水平管内に気液 2 相を並流させた研究る特定の目的の ためには興味あるすのと考える。

\section{㣮}

(1963)

15) E. R. Gilliland and T. K. Sherwood: Ind. Eng. Chem., 28. 516 (1934)

16）萁田文5，化工，18，73，174 (1954)

17) 疋田蔽夫5, 化工, 23，23，28，459（1959)

18) 井三郎5, 化工, 20, 65 (1956)

19）只木模力5, 化工, 27, 66 (1963)

20）内田传一田交, 工化, 37, 1578, 1583, 1589, 1707 (1934); 39. 876 (1936) ; 41, 563 (1938)

21) E. Kirschbaum, V. D. I., 75, 1212 (1931)

22) T. C. Baker, et al. : Trans. Am. Inst. Chem. Engrs., 31, 296 (1934)

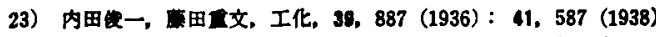

24) Meyo, et al.: J. Soc. Chem. Ind., 54, 375T (1935)

25）疋田明夫5, 化工, 20,528 (1956)

26) Walker, Lewis, and McAdams : "Principles of Chemical Engineering," 2nd Ed. (1927) ; W. K. Lewis and W. H. McAdams : Ind. Eng. Chem., 20, 253 (1928)

27) T. H. Chilton and A. P. Colburn: Ind. Eng. Chem., 27, 255 (1935)

28）恩田榙三郎，佐由栄三，化工，22，194（1958）；23，220 (1959）； 24. 490 (1960)

29）矢木栄5, 化 ，15, 317 (1951)；化工, 17, 216 (1953)；18, 2, 9, 179 (1954)

\section{特別寄谸}

欧米におけるガス吸収研究見聞記*

$$
\text { 恩 田 格 三 郎** }
$$

去る 3 月 10 日羽田を出発してから約 3 カ月イタリー, ドイッ, オランダ、フランス, イギリス、フメリカと各 大学ならびに研究所を回って来た。しかし限られた日数 々費用のため，また事前の打合せゃ調查が不十分なため

\section{- 昭和 38 年 7 月 31 日妥理}

** 名古量大学数流
に面会できなかった方や，颜問できなかった所すあって 必ずしす当初予定していた全部の大学，ならびに研究所 を歴㵊しえたわけではないか，現在いかなるテースのす

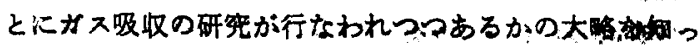
ていただくとともに，今啳欧米に行かれる方の何らかの 
こ参考になればと思ってあえてこの一文を草した。与え られた数が少なく，かつ装置の説明は紙上では非常に 困難であるため、ほんの概説になってしまったことをあ らかじめおかびいたす次第である。

\section{Karlsruhe の Technische Hochschule}

Karlsruhe はStüttgart から自動車で 1 時間，また は汽車で 1 時間 20 分くらい, 雑木林と野原の間を行っ た所にあり，建物は媡瓦造りで古風であるが内部設備は ほとんどが大戦後組立てられたすので新しい。ここの研 究の主力は孔の直径が 1” ああるシーブトレーによる精 留であり, 目下バラストトレーとの比較研究が行なわれ ている。Prof. Kirschbaum のもとにK. Höffer, 0. Nagel, R. Thomat, R. Schmidt の 4 人の Mitarbeiter がおり 20 人の職工を使って実験していた。 $10 \mathrm{~m} \times 50 \mathrm{~m}$ の部屋に直径 $1 \mathrm{ft}$. から $3 \mathrm{ft}$. までのシーブトレー，小型 の噴霧針燥機，バラストトレー，自動循還精留塔など約 10 基がならんで,いずれる運転されているのは壮観であ った。しかし、ガス吸収に関しては濡壁塔による夜の蒸 発装置があったのみである。

\section{Delft $の$ Technological University}

Amsterdam から夸車で 1 時間の所にあり, 建物は前 大戦で破壊され戦後改策されたモダンなるの。直径 1 $\mathrm{mm}$, 長さ $2 \sim 10 \mathrm{~cm}$ の層流の液ぜットによる NOCl の 吸収、需れ壁による亜硫酸ンーダの酸化反応の実験をや っていた。さらに $1 \mathrm{ft}$. の直径, $10 \mathrm{ft}$. の高さの塔に $1 "$ のラシヒリングをつめて, 液の方は $\mathrm{NaCl}$ を, ガスの方 は $\mathrm{C}_{4} \mathrm{H}_{10}$ をトレーサーとして, 空気 $-10 \% \mathrm{Na}_{2} \mathrm{SO}_{3}$ 水溶 液系の濡留時間分布を測定していた。そのさい $\mathrm{C}_{4} \mathrm{H}_{10}$ は 高温における flame ionization detecterによってその 濃度を剆定していた。

Prof. H. Kramer のととに, Dr. C. A. P. Bakker, R. M. Voncken, L. H. J. Wachtero, K. J. A. de Waal らの Lecturer がいる。

\section{New Castle $の$ Kings College}

New Castle は北縺 $55^{\circ}$ ，London から飛行機で 2 時 間, 汽車ならば 4 時間の距離にあり, 現在は，Durham Universityの 1 College であるが近々独立して New Castle University になるとのことである。

Lecturer, Dr. F. Coodridge の Inclined Trough $に$ よるガス吸収では, Trough の壁の傾斜と流速分布との 関係をしらく，Trough の壁が垂直より $30^{\circ}$ 傾斜した場 合に流速分布は一様になることを見い出していた。さら に，ガスと液とを別個に擋拌しておいいて， C'をトレー

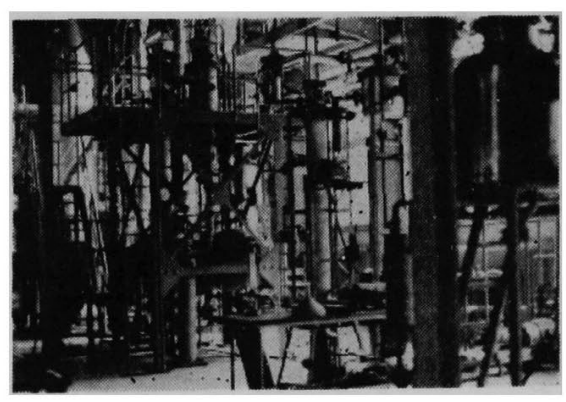

军共 1 Karlsruhe Technische Hochschule の実験室の一部正面はバラストトレー

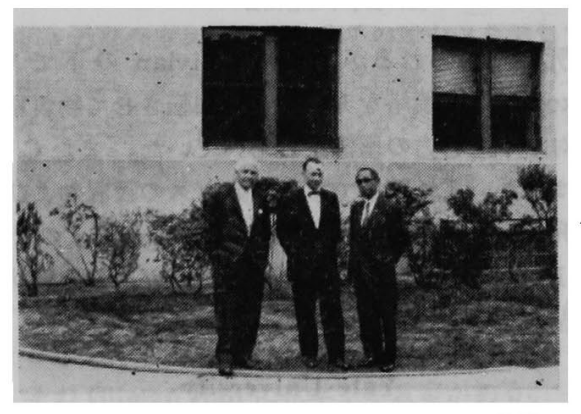

写真 2 Prof. Sherwood, Vivian ならびに筆者, 後方は M. I. T. の化学工学の建物

サーとする $\mathrm{CO}_{2}$ のガス吸収を行なわしめ、それによっ て界面抵抗を測定していた。また $\mathbf{C}^{14}$ をレーサーとし て充填塔の有効接触面積をはかららとしていた。

\section{Cambridge University}

Cambridge は London から汽車で約 1 時間, Cam 河 畔にある道幅の狭い大学町であって, 大学は 25 の College からなっている。筆者はそこの Shell Buildingに Prof. Danckwerts 訪ねた。G. M. Richardsは, 1/2" のラシヒリングを充填した充填塔で $\mathrm{HCl}$ を触媒と して Dimethyl acetal の水による加水分解を $120 \mathrm{~mm}$ $\mathrm{Hg}, 25^{\circ} \mathrm{C}$ の条件下で行なって, 充填塔に括ける表面年 龄分布関数を測定していたが，そのさい求められた有効 接触面積は，筆者らが測定した濡れ面積と全く一致して おり，大変愉快であった。さらに Dr. Davidsonの下 で， G. J. Jomeson は液柱に振動を与えるときは，上 方から吹き込んだ気泡が重力に反して下方に進む現象に よる気体の吸収を研究している。また鉛の細かい粒と水 との中の airの上年などを調でていた。

\section{Massachusetts Institute of Technology}

M. I. T. は Boston から Charles 河にかかる Harvard Bridge を渡った Cambridge にある秝立大学であ る。Prof. T. K. Sherwood は現在は主として触蝶反応 


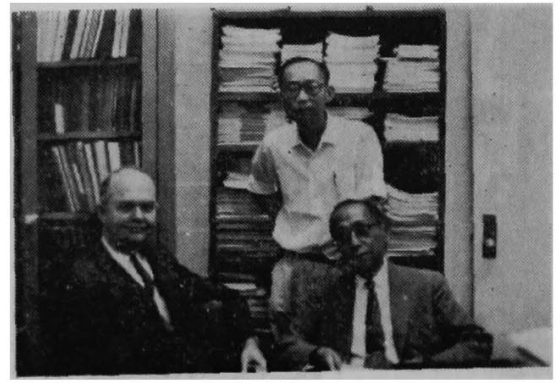

军真 3 Prof. Pigford と筆者，中央は住友化学 から派遗された Delaware 大学の大学 完に在学中の吉川政

を研究していられるか， Prof. Vivianの下てV.J. Krukonis は充填塔を非常に速く回転させて物䁈移動俰 数に対する遠心力の影翼をしらべていた。またC. Piozza は短かい濡れ壁荅で水々塩素ガスの吸収および放散 の研究を行なっており，また Prof. Mickleyの下では E. I. Korckok が充填塔中の液およびガスの流動状隼の 研究を行なっていた。

\section{Yale University}

New Heaven の街は Heiderberg in west といわれ るだけあって樹木の多い静かな街である。しかし Yale University の保守性は 3 年前に建造された建物が旧態 依然たる空の小さい煉瓦建の建物であることによっても らかがえる。ここの Prof. Dodge は高圧実験装置を数 多く用いて Compressibility の測定を行なっていた。

\section{University of Delaware}

本大学のある Newark は, New York のすぐそばに ある Newark とは異なり, Du Pont の本拋の Wilming ton から自動車で 1 時間はどの所にある小さな町であ る。ここでは, Prof. R. L. Pigford, J. A. Gerster, A. B. Metzner らが多くの大学院学生を持って物筫移動の 研究をしていられるが、筆者が訪れたときはあいにく学 期末で玨とんどの実験は停止中であり、あまり多くの実 験設備は見られなかった。しかし Prof. Pigfordの下で

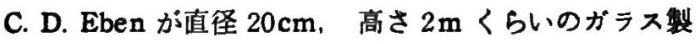
の bubble tray を用いて化学反応を伴 $5 カ ゙ ス$ 吸収の実 験を行なっており，またW. B. Lambはジャバラを使 って水平面上のガスの王力を周期的に変化させて, Dynamics of Interface を研究していた。Prof. Met・ zner の下では, J. R. Hopper が安息香酸を哂った長さ

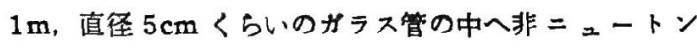
流体を流して壁からの拡散速度を測定していた。

また Associate Prof. J. R. Ferron の下では T. A. Pakurar がガスバーナー中に $\mathbf{C}^{14}$ の庅酸ガスを注入す

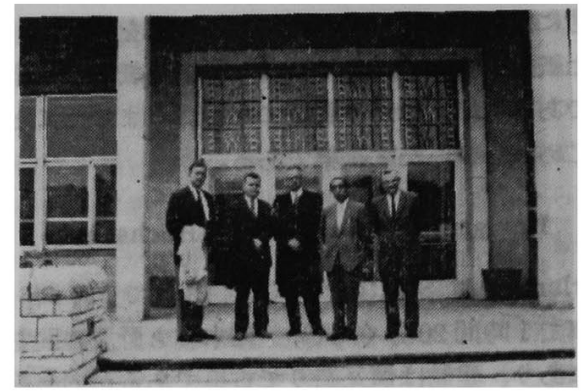

军真 4 向って左か.5 Prof. Lightfoot, D. F. Rudd, C. C. Watson, 筆者および Chairman o R. A. Ragatz, 徏方は Assembly Hall の玄閏

る方法によって高温におけけるガスの拡散係数を测定して いた。Du Pont の研究所が大学のすぐ近くにあり,かつ Pigford, Gerster, J. H. Olson らはいずれる以前は Du Pont にいた人達であるから,さためし Du Pont との結 び付きが密接であろらと想像されるが, Pigford 教授は それをはっきり否定され，その証拠に Du Pontは全》 メリカにおいて，数百人の大学院の学生に研究費を出し ているが, Delaware 大学では化学工学で 1 人, 化学で 1 人のわずか 2 人しか鿓っていないといっておられた。

\section{University of Pennsylvania}

Newark から Du Pont の旧邸を経て，工場の建ら並 今 Industrial Highway を自動車で的 2 時間で Philadelphia に着く。そこの Wolnut Street と 33rd Street の交叉点の広場の西にある Towne Building が化学工 学の建物である。ここで Prof. M. C. Molstadは現在 は主としてプロセス制御の研究をしていられるが, 混合 ガスの圧縮係数や水中における回転体上の安息香酸の溶 解速度などを調べていけ。

しかし、ここはすでに休昵中で学生はほとんどいなか った。

\section{University of West Virginia}

Pittsburgh からパスで 2 時間半の所に Morgantown がある。小山と, 棵の多い小さな町である。この大学の Engineering Building は昨年できたばかりで未だ引越 が完了しておらず，装㯰は多く荷造りされたままであ り，大学院の研究は主として、ここから南西䄪 100 マイ ル離れた Charleston にある Kanawha Valley Graduate Center で行なわれているようであった。この大学 Kは, Aero-space Engineering Department があり, 重力の無い埸ではローソクの炎が消えてしまうという現 象や、 コップの水が表面張力のために上から出て行くと いらょうな間題を検討しているとのことであった。 


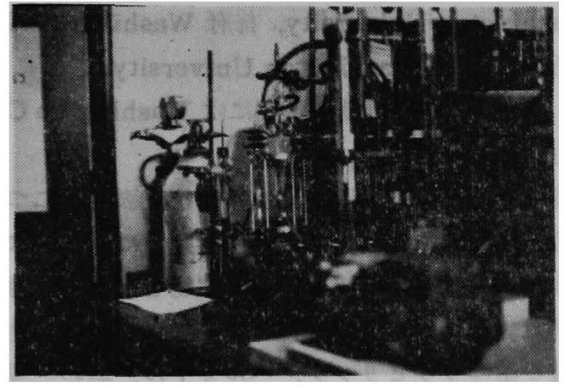

军真 5 Master course の方に使われている，いわ 中る Modified Onda's Apparatus. 中央 のガラスの部分が jet の落らる部分。Doctor Course の方のはこれよりやや大型であるが あいにく洗涑中で取りはずしてあった。

\section{University of Wisconsin}

本大学はシカコから汽車で 3 時間, 急行バスで 2 時間 半の Madison にある。ここは Mendota 湖と Monona 湖の二つの大きな湖に挑まれた景色の良い町で, 州庁が

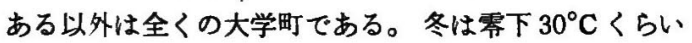
になるが夏の日射も強いので来年 2 月にできる化学工学 の建物は空をすへて北向きとし暖房だけを考えるといっ ている。Prof. W. E. Stewart は, 内径約 $10 \mathrm{~cm}$, 長さ 約 $20 \mathrm{~cm}$ の肉圧円筒 2 個をつなき合せて高圧における 気体の拡散係数を湘定していた。Prof. E. N. Lightfoot は 3 成分采の液の拡散係数の測定を行なっていた。

\section{Texas University}

Texas 州庁のある Austin の北部の高台にある大学 である。Cornell University の Associate dean であ る Dr. J. E. Hedrick が 1959 年にアメリカの化学 工学 科の教授人容, 研究業績, 設備, 授業内容などを調査し てベスト12の大学, 研究所の名前をあげているが, その 中に入っているのは南部では，本大学のみであるとい 5。Associate Prof. D. M. Himmelblau は筆者らが化 工誌（24，918，1960）に発表した液柱塔とほぼ同様な 彼のいうか Modified Onda's Apparatus を2台用い $て$ Doctor course と Master course の学生を使い, $\mathrm{CO}_{2}$ の水中に扮ける扗散俰数を測定し, 筆者らが $\mathrm{CO}_{2}$ の飽和度 $50 \%$ の之は, 純水中の拡散係数の約 $75 \%$ に 減少すると発表したのに対して，䄪 90\%になるとい5 結果を出されていた。

このほか層流で流れている水中に， $\mathrm{C}^{14}$ を含んだ $\mathrm{CO}_{2}$ を注入し，一定距離（約 $10 \mathrm{~m}$ ) 離れた所の濃度分布を 测定する方法によっても払散係数を測定していた。また Assistant Prof. K. B. Bischoff は合成樹脂でできた, 直径約 $5 \mathrm{~mm}$ の球の充填層中に窒素ガスとイオン化し

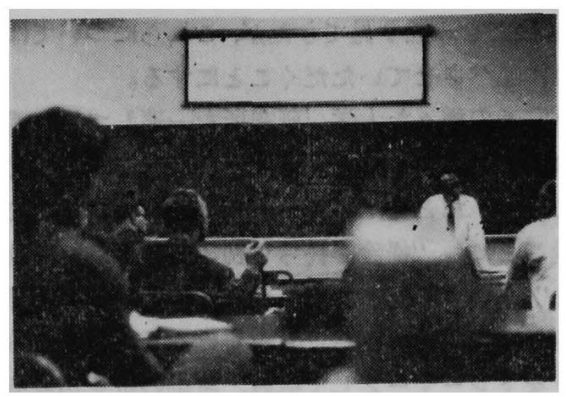

写真 6 Delaware 大学にて䜊演中の篗者

た He との混合ガスを通した後その球をとりだして検知 管の中に入れ，その合成樹脂球に付着した微量の $\mathrm{He}$ を 测定することによって充填層中のガスの分布状態を検し ていた。

\section{University of California}

サンフランシスコからかけられた長さ 8 マイル余の大 きな Bay Bridge を渡った Berkeley の高台にある大学 でその Gilman Hall に化学工学教室がある。しかし この大学では Yale 大学と同じように化学と化学工学と が一体となっており，したがって研笔も電気化学の物質 移動が主体となっている。ガス吸収関係では，並流によ るガス吸収，多孔質の円擣から水をしみ出させて空気中 に放散させる迅速な物質移動の研究, 油の流れの中に円 柱を置いてその後部に生じる Vortex に関する研究など が行なわれていた。

筆者はこのたびの旅行において, Venice の郊外の, Petro-Coke 株式会社, Paris の郊外 Rueil-Malmaison にある石油化学研究所, Delaware 大学, Wisconsin 大 学, California 大学において, “精留塔の段効率につい でおよび “充填荅における物質移動係数について” と 題して講演を行なった。写真6は Delaware 大学にお いて大学院学生 15〜16 名ならびに Gerster, Metzner 教授らを前にして精留塔の段効率に関する筆者の新提 案について講演しているところである。中央が Prof. Gerster。

化学工学の Bachelor の学生実験用の装膡はいずれの 大学も大同小異であったが, Berlinの Technische Universität の Prof. Kolbe の所では, いささか観覧者 用かと疑われるほど，流動乾燥装置，プラスチック製の フィルタープレス, 小型精留塔, 水添装置, 㴆留時間測 定用のカスケードなどの装置が 20 題目にわたって実に 器用に小型に造られているのには感心した。その他, Arnhem の A. K. U. の研究所, Buffalo の近くにある Durey の Plastic の工場, Morgantown の Bureau of 
Minesなどを一通り見てきたがこれらについてはまた の機会に述べさせていただくことにする。

以上欧米の種々な大学, 研究所を一巡して特に感じた ことは，各実験室の清掃，整理が良く行きとどいている ことである。たとえば, West Virginia 大学などでは, 各部屋ことに，“淿除が終って初めてあなたの実検は終 了する”という標語がはられており，実験能率々部屋の 乱雅さとは無関係であることを痛感した。また全体とし て $\mathrm{C}^{14}$ をレーサーとして拡散, 流動の研究が数多く行

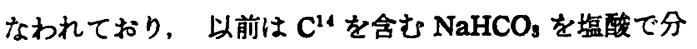
解して $\mathrm{C}^{14}$ を含む $\mathrm{CO}_{2}$ を得ていたが最近は，ボンべで 直接 C'4 含む $\mathrm{CO}_{2}$ ガスが睛入されるようになったと いらことである。值段は $\mathrm{NaHCO}_{3} 1$ mili curieがイギ リスで 4 ボンドくらいであり，その Detector はフメリ カで数千ドルくらいである。またフメリカにおいては気 体の压樎係数あるいは拡散保数の測定など基磷的なるの が多いのが目につくか，これは，Prof. Sherwood 指 摘されたのであるが深学金の成倸である。すなわち、フ メリカの科学関保で最大の学金を出す National Science Foundation が基碳研究に主として金を出すたてま えであるからである。

さらにその額であるが, これはもちろん人によって大 いに異なるのであるが，筆者の開いたところでは， Texas 大学の Associate Professor Himmelblau は本年 39 葴であるか，その 1962 年度の奖学金が 30,000ドルと いらのであるから全くららやましいかきりである。るっ ともこの中には大学院学生もしくは, Research Associateの费用 1 人 1 年 $2,400 \sim 5,000$ ドルが含まれている のである。

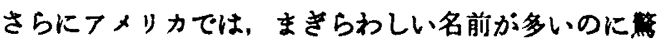
く。たとえばワシントン大学は次のように少なくとも五 つあるのである。Washington 州の Pullman にある, Washington State University, Seattle にある University of Washington, Missouri 州の St. Louis にあ
る Washington University, 首府 Washington, D. C. にある, George Washington University, さらにNew York の Manhattan 島の東側には Washington College があるのである。

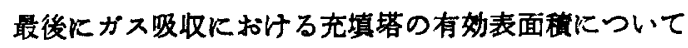
であるが、これに関して筆者らの研究室においては，濡 れ表面程が有奻表面積であるとの立場をとって，容量係 数を濡れ表面皎で除して得たガス側ならびに液側物質移 動係数を磁性ラシヒリンク，ベルサドル，球の三種の充 填物のいずれにる適合する簡単な無次元式でまとめるこ とに成功し，かつそのようにして满かれたガス側物質移 動係数は loading point 以下では液流速に無関倸になる とい5興味ある現象を見い出し，反応を伴うガス吸収で は有効表面䄸が濡れ表面稓に一致するとい5事実を確認 し、前述せる如く Danckwerts の研究室の Richards

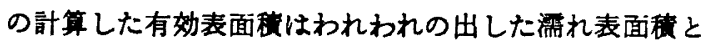
全く一致するという結果を得たのであるが，これに対し New York 郊外にある Clarkson College の Prof. H. L. Shulman および京大の吉田文武教授らは充填塔のガ ス吸収と同じ機權の物質移動をなすと彼らが推定した実 鈋結果より落いた物質移動係数で容量係数を除して有効 表面碳を出しておられる。その結果は操作条件その他の 裤雑な関数となり，それに基ずいて大阪府大の正田教授 は有効表面䅡は液側とガス側で異なると言っておられ る。このことに関連して昨年まで Assistant Prof. とし て M. I. T.におられ，本年 University of California に移られた Prof. C. M. King は次のよらに筆者に語っ た。

「周知の $1 / K_{G} a=1 / k_{g} a+1 / H k_{L} a$ の関係式が徑少表面 程にるまた通常，測定されるよ5な稜分表面秷にもひと しく成立するためには， $k_{\mathrm{g}}=c k_{\mathrm{L}}$ の周係（たたし $c$ は积 分に無関係な常数) が常に成立する必要があるとの議諭 を当時同大学を訪門中の吉田教授に吹きかけて同教授を 悩ました。よのことである。 